Canadian Science Publishing

Canadian Journal of Earth Sciences Revue canadienne des sciences de la Terre

\title{
A primitive clupeomorph from the Albian Loon River Formation (Northwest Territories, Canada)
}

\begin{tabular}{|r|l|}
\hline Journal: & Canadian Journal of Earth Sciences \\
\hline Manuscript ID & cjes-2015-0172.R1 \\
\hline Manuscript Type: & Article \\
\hline Date Submitted by the Author: & 18 -Jan-2016 \\
\hline Complete List of Authors: & $\begin{array}{l}\text { Vernygora, Oksana V.; University of Alberta, Biological Sciences } \\
\text { Murray, Alison M.; University of Alberta } \\
\text { Wilson, Mark V. H.; University of Alberta, Biological Sciences }\end{array}$ \\
\hline Keyword: & Osteichthyes, Teleostei, Cretaceous, phylogeny, Ellimmichthyiformes \\
\hline
\end{tabular}

\section{SCHOLARONE ${ }^{\text {TN }}$ \\ Manuscripts}


RH - FOREYCLUPEA FROM NORTHWEST TERRITORIES

1

2

3

4

$5 \quad{ }^{1}$ Department of Biological Sciences, University of Alberta, Edmonton, Alberta, T6G 2E9,

6 Canada

$7 \quad{ }^{2}$ Loyola University College, Chicago, USA

$8 \quad *$ corresponding author: vernygor@ualberta.ca
Canada)

Oksana Vernygora* $^{* 1}$, Alison M. Murray ${ }^{1}$, and Mark V. H. Wilson ${ }^{1,2}$

10 


\section{RH - FOREYCLUPEA FROM NORTHWEST TERRITORIES}

12 Abstract: Foreyclupea loonensis, gen. et sp. nov., is described from the early/middle Albian

13 Loon River Formation of the Northwest Territories, Canada. The only specimen of the new

14 species was originally described as a part of an enigmatic taxon Erichalcis arcta in 1975, which

15 was assigned to the Clupeomorpha. Since then, E. arcta has proven to be a composite taxon,

16 made up of clupeomorph and non-clupeomorph specimens. The non-clupeomorph material was

17 redescribed as a Euteleostei incertae sedis and retained the species name.

Described herein is the fossil clupeomorph specimen originally assigned to Erichalcis arcta. As in other members of the superorder Clupeomorpha, the ventral margin of the body in the specimen is covered with spiny scutes and the supratemporal commissural sensory canal

21 passes through the parietals. Along with these diagnostic characters, the new taxon also shows

22 primitive traits of the basal members of the group, including a medioparietal skull roof, unfused

23 halves of the neural spines of the abdominal vertebrae, and no evidence of presence of the

24 recessus lateralis. When included in a phylogenetic analysis of the Early Cretaceous

25 clupeomorphs, the new species forms a clade with the Early Cretaceous clupeomorphs from

26 Mexico and Brazil, Ranulfoichthys dorsonudum and Scutatuspinosus itapagipensis respectively. 
RH - FOREYCLUPEA FROM NORTHWEST TERRITORIES

\section{Introduction}

The extant members of the superorder Clupeomorpha (herrings and allies), all in the order

33 Clupeiformes, include more than 400 species in both marine and freshwater habitats, and include some of the most numerically abundant and commercially most important fishes, but little is

35 known about their early evolutionary history. The majority of fossil members of this group are placed in the extinct order Ellimmichthyiformes. The earliest fossil record of the clupeomorph

37 fishes dates from the early Early Cretaceous deposits of Europe, Asia, and South and North America. Already at that time clupeomorphs had a broad environmental distribution, occurring in freshwater, marine, and brackish water settings. Their remarkable ecological plasticity apparently allowed for a successful dispersal worldwide. The most diverse and abundant fossil material of this group of fishes is known from the Aptian-Albian deposits of Brazil and from

42 Late Cretaceous deposits of the Mediterranean region (e.g. Poyato-Ariza et al. 2000; Taverne 43 2002; Chang and Maisey 2003; Forey et al. 2003; Malabarba et al. 2004; Murray and Wilson 44 2013; Silva Santos and Silva Correa 1985). These deposits have yielded a large number of 45 ellimmichthyiform taxa.

In Canada, the early fossil record of the Clupeomorpha is limited to only a few mid- to

47 Late Cretaceous species: Horseshoeichthys armaserratus Newbrey et al. 2010, from the Maastrichtian Horseshoe Canyon Formation, Tycheroichthys dunveganensis Hay et al. 2007,

49 from the Cenomanian Dunvegan Formation, and an enigmatic taxon, Erichalcis arcta, first described by Forey (1975) from the early/mid Albian deposits of the Loon River Formation.

51 Description of the last taxon was based on sixty nine specimens collected in 1972 that showed a 52 perplexing combination of characters. Forey (1975) recognized Erichalcis as Clupeiformes 


\section{RH - FOREYCLUPEA FROM NORTHWEST TERRITORIES}

53 incertae sedis mainly based on the presence of abdominal scutes; however, he noted that unlike

54 other clupeomorphs the new taxon had enlarged modified scales along the lateral midline of the

55 body and showed specialized features of the caudal skeleton - fusion of the upper hypurals, first

56 preural centrum without a neural arch, and laminar flanges associated with the haemal spine of

57 the second preural centrum and neural spines of the third and second preural centra. This

58 perplexing combination of characters led Forey (1975) to the conclusion that Erichalcis

59 represented a primitive clupeomorph and could not be classified as a member of either

60 Denticipitoidei or Clupeoidei.

61 In his monograph on the classification of the clupeomorph fishes, Grande (1985) placed

62 Erichalcis in his monotypic Division I as the sister group to all known recent and fossil

63 clupeomorphs. He referred to a few specimens from the University of Alberta Laboratory for

64 Vertebrate Paleontology (UALVP) collections, including the holotype (UALVP 8606) showing

65 enlarged lateral line scales, paratypes UALVP 8598 and UALVP 8629 with modified caudal

66 skeletons, and UALVP 17535 showing a complete series of abdominal scutes (Grande, 1985, fig.

$675 \mathrm{D})$.

Subsequent re-examination of the holotype and a number of paratype specimens of

69 Erichalcis arcta led Arratia (1997) to the conclusion that this taxon belongs to the Euteleostei

70 and is more closely related to salmoniforms than to clupeomorphs. Later, Hermus et al. (2004)

71 described another species of Erichalcis, E. conspicua, from the middle Albian Christopher

72 Formation, Nunavut, Canada. Similar to the type species, E. conspicua has enlarged, modified

73 lateral mid-line scales diagnostic for the genus. These studies showed that the original Erichalcis

74 arcta was a composite of euteleost and clupeomorph taxa; however, they did not investigate

75 further the clupeomorph material originally assigned to Erichalcis arcta sensu Forey (1975). 
RH - FOREYCLUPEA FROM NORTHWEST TERRITORIES

In the present study, we describe the clupeomorph specimen that was originally a

77 paratype of Erichalcis arcta. This work includes morphological and phylogenetic analyses of specimen UALVP 17535, which represents the oldest known clupeomorph from Canada.

\section{Geological setting}

The fossil fish material was recovered from the Loon River Formation cropping out along the Hay River, southern Northwest Territories $\left(60^{\circ} 01^{\prime} \mathrm{N}, 116^{\circ} 57^{\prime} \mathrm{W}\right)$. This formation is part of the Fort St. John Group and is dominated by black marine shales and limestones. This locality has yielded a number of vertebrate taxa including a holostean, an aspidorhynchiform, an ananogmiid, euteleosts, and at least two genera of ichthyosaurs (Forey 1975; Hermus et al. 2004; Maxwell and Caldwell 2006). The Loon River Formation has been dated as early to middle (Hathway et al. 2013).

\section{Material and Methods}

Description of the new taxon is based on a single specimen preserved in part and counterpart in black laminated shales. The specimen is incomplete, with only the anterior part of

95 the fish preserved. This is the only specimen showing the abdominal series of scutes in the original collection of the fossil fish material from the locality catalogued in the collections of the

97 University of Alberta Laboratory for Vertebrate Paleontology (UALVP). The specimen is catalogued as UALVP 17535, the part being 17535a and the counterpart 17535b. 


\section{RH - FOREYCLUPEA FROM NORTHWEST TERRITORIES}

The morphological description is based on examination of the original specimen and of a

100

101

102

103

104

105

106

107

108

109

110

111

112

113

114

115

116

117

118

119

120

121

\section{Comparative material}

The following taxa of extinct and recent clupeomorphs were examined for the purpose of morphological analysis and comparative study: Alosa sappidissima (Wilson, 1811): Z-366; Armigatus brevissimus (Blainville, 1818): UALVP 5087, 17620, 47258; Diplomystus dentatus (Cope, 1877): UALVP 17731, 21163, 22860, TMP 1986.224.0081, 1986.224.0083 - 0086, 1986.224.0088 - 0091; Dorosoma cepedianum (Lesueur, 1818): Z-441; Horseshoeichthys armaserratus Newbrey et al., 2010: TMP 2001.045.00931; Sorbinichthys africanus Murray and Wilson, 2011: UALVP 51640 (holotype), 47186, 51641; Thorectichthys marocensis Murray and Wilson, 2013: UALVP 47178 (holotype), 51647, 51649, 51657, 51659; T. rhadinus Murray and Wilson, 2013: UALVP 51653 (holotype), 51664.

Institutional abbreviations: UALVP, University of Alberta Laboratory for Vertebrate Palaeontology, Edmonton, Alberta, Canada; TMP, Royal Tyrrell Museum, Drumheller, Alberta, Canada; Z, zooarchaeology collections of the Canadian Museum of Nature, Ottawa, Ontario, Canada.

\section{Phylogenetic analysis}

Cladistic analysis was performed using TNT 1.1 (Goloboff et al. 2008) employing a heuristic search method with 1000 replicates and tree bisection and reconnection (TBR) swapping algorithm. The most parsimonious trees (MPTs) retrieved by the initial analysis were 


\section{RH - FOREYCLUPEA FROM NORTHWEST TERRITORIES}

122 used to construct strict consensus tree. Mesquite v 3.03 (Maddison and Maddison 2011) was

123 used to construct a character matrix for the analysis and calculate tree length, and consistency

124 (C.I.) and retention (R.I.) indices for the consensus tree. Ancestral state reconstruction was also 125 carried out in Mesquite v 3.03 (Maddison and Maddison 2011).

The character matrix used for the phylogenetic analysis includes a total of 17 taxa and 62

127 characters (Appendix 1). We used ten early Cretaceous ellimmichthyiform taxa along with two

128 Early Cretaceous putative clupeiforms (Pseudoellimma gallae, Santanaclupea silvasantosi),

129 three extant clupeiform taxa (Chirocentrus dorab, Odaxothrissa vittata, and Denticeps

130 clupeoides), and the gonorhynchiform Chanos chanos (Forsskål 1775) (as a representative

131 member of the Ostariophysi, sister group to the Clupeomorpha) for the purpose of out-group

132 comparison.

Character descriptions and states were adopted from previously published works by

134 Zaragüeta-Bagils (2004), Alvarado-Ortega et al. (2008), and Murray and Wilson (2013). The

135 new taxon was scored based on the morphological description provided in this study and

136 included to the character matrix (Appendix 2). All characters are unordered and equally

137 weighted. Missing data for the characters are coded by question marks; inapplicable characters

138 are coded by dashes.

\section{Fossil taxa included in the phylogenetic analysis}

Ellimma branneri (Jordan, 1910); Ellimmichthys goodi (Eastman, 1912), Ellimmichthys

142 longicostatus (Cope, 1886), Ellimmichthys maceioensis Malabarba et al., 2004; Ezkutuberezi

143 carmenae Poyato-Ariza et al., 2000; Paraclupea chetungensis Sun, 1956; Pseudoellimma gallae

144 Figueiredo, 2009; Ranulfoichthys dorsonudum Alvarado-Ortega, 2014; Santanaclupea 
RH - FOREYCLUPEA FROM NORTHWEST TERRITORIES

145 silvasantosi Maisey, 1993; Scutatuspinosus itapagipensis Silva Santos and Silva Correa, 1985;

146 Triplomystus applegatei Alvarado-Ortega and Ovalles-Damian, 2008.

148 Systematic Paleontology

149 Subdivision Teleostei Müller, 1845

150 Cohort Clupeocephala Patterson and Rosen, 1977

151 Superorder Clupeomorpha Greenwood et al., 1966

152 Order Ellimmichthyiformes Grande, 1982

153 Family Scutatuspinosidae Silva Santos and Silva Corréa, 1985, new rank

154 Genus Foreyclupea, gen. nov.

155 DIAGNOSIS: as for type and only known species.

156 ETYMOLOGY: the genus is named in honor of Dr. Peter L. Forey in recognition of his great 157 contributions to paleoichthyology and his first description of the fossil fish material from the 158 Loon River Formation; and from the Latin 'clupea' to indicate clupeomorph affinities of the new 159 taxon.

160 TYPE AND ONLY KNOWN SPECIES: Foreyclupea loonensis, sp. nov. 161

$162 \quad$ Foreyclupea loonensis, sp. nov.

163 (Figs. 1-3)

164 DIAGNOSIS: clupeomorph fish with a shallow body differing from other ellimmichthyiforms 165 (except Ranulfoichthys dorsonudum) in having at least two broad postcleithra and lacking 166 predorsal series of scutes; distinguished from $R$. dorsonudum by the pelvic fin insertion anterior 


\section{RH - FOREYCLUPEA FROM NORTHWEST TERRITORIES}

167 to the origin of the dorsal fin and abdominal scutes with spine-like ascending lateral wings with 168 strengthening ridge at the posterior margin.

169 ETYMOLOGY: the specific epithet is derived from the name of the formation where the 170 specimen was found.

171 HOLOTYPE: UALVP $17535(\mathrm{a}, \mathrm{b})$ a single specimen in part and counterpart. The part showing 172 the specimen in left lateral view (UALVP 17535a) preserves the complete head and anterior part 173 of the body; the counterpart (UALVP 17535b) has only the postorbital part of the skull and the 174 anterior part of the body preserved.

175 LOCALITY: Loon River Formation, Hay River, Northwest Territories, Canada. 176 AGE: Early/middle Albian (Early Cretaceous).

\section{Description}

\section{General body form}

This is a slender fish with a shallow body similar to that of some other Early Cretaceous clupeomorphs - Scutatuspinosus itapagipensis, Ranulfoichthys dorsonudum, and Santanaclupea silvasantosi (Silva Santos and Silva Correa 1985; Maisey 1993; Alvarado-Ortega 2014). The dorsal margin of the body, although distorted, seems to run in a smooth and straight line from the back of the head to the origin of the dorsal fin (Fig. 1). The predorsal part of the

185 trunk appears to be uniformly deep with the body depth equal to $19 \mathrm{~mm}$. The posterior part of the 186 fish, including the anal and caudal fins, is missing and thus the standard length (SL) of the fish 187 cannot be determined. The total length of the preserved portion is $56 \mathrm{~mm}$. We estimate the SL of 188 this fish would have been about $100 \mathrm{~mm}$, if the proportions of this fish were similar to those of 189 the three other Early Cretaceous clupeomorphs mentioned above (Fig. 2). The head is preserved 


\section{RH - FOREYCLUPEA FROM NORTHWEST TERRITORIES}

190 in lateral view; it is relatively narrow, triangular and about 1.4 times longer than deep. The dorsal 191 profile of the skull is a straight line from the tip of the snout to the back of the skull. Only the

192 dorsal, pectoral, and pelvic fins are preserved in the specimen. The pelvic fin insertion is slightly

193 farther anterior than the dorsal fin origin. Measurements and counts of the specimen are 194 summarized in Table 1.

Skull

Skull bones are not well preserved, with many elements crushed, displaced or preserved 198 only as impressions. The head, as is typical for clupeomorphs, is triangular and relatively narrow with a pointed snout (Fig. 3).

The ethmoid region of the skull is partially preserved with only the mesethmoid and lateral ethmoid visible in the specimen. The mesethmoid is a well-ossified bone with a blunt and bilobed anterior end that contacts the maxillary and premaxillary bones; however, details of the articulation cannot be determined. Posteriorly, the mesethmoid has two elongate processes that suture with the frontal bones. The lateral ethmoid is only partially visible in the specimen; it 205 appears to be large, extending from the frontals to reach the parasphenoid.

207 regions of the skull; they are narrow anteriorly and gradually expand posteriorly where they 208 suture with the parietal and pterotic bones. The frontals contact each other in the midline leaving 209 no frontal fontanelle; there is also no posttemporal fossa. In the posterior part, the frontal bones 210 are ornamented with deep sinuous ridges similar to those in Pseudoellimma gallae (Figueiredo 211 2009; Fig. 3). 


\section{RH - FOREYCLUPEA FROM NORTHWEST TERRITORIES}

212

213

214

215

216

217

218

219

220

221

222

223

224

225

226 227 confirmed.

228

229 Orbital region and hyopalatine bones

230

231

232

233

234

\section{Orbital region and hyopalatine bones}

The supraorbital sensory canal runs through the frontal bones. It is visible in the posterior

part of the left frontal where the sensory canal becomes bone-enclosed. At the suture between the frontal, parietal and pterotic bones, the supraorbital canal gives off at least two branches.

The pterotic is a relatively large, wedge-shaped bone that contains the bone-enclosed supratemporal sensory canal. There are no openings for a recessus lateralis in the pterotic. The parietals are relatively small trapezoidal bones, located just above the posterior portion of the orbit. They are not separated by the supraoccipital and so contact each other in the midline (medioparietal condition). The suture between the parietals is not deeply sinuous as in Ranulfoichthys dorsonudum (Alvarado-Ortega 2014). The right parietal is marked with a transverse groove for the supratemporal commissure that is one of the diagnostic characters of the Clupeomorpha (Grande 1985). The parietal bones are ornamented with only a few sinuous ridges, much less pronounced than those of the frontals.

The supraoccipital is poorly preserved and only a low crest is distinguishable behind the parietals. The lateral surface of the braincase is distorted and it is impossible to determine details of the individual bones. Presence or absence of the recessus lateralis in the specimen cannot be

Circumorbital bones are not preserved in the specimen; only impressions of infraorbitals 3 and 4 can be identified. Infraorbital 3 is located in the posteroventral part of the orbit and appears to be a relatively large and expanded bone with an open groove for the infraorbital sensory canal (Fig. 3). The sensory canal continues dorsally where only a partial impression of infraorbital 4 is visible. A partially preserved bone in the posterodorsal portion of the orbit is 


\section{RH - FOREYCLUPEA FROM NORTHWEST TERRITORIES}

235 identified as the sphenotic. Presence of the antorbital and supraorbital bones cannot be 236 confirmed.

The parasphenoid is narrow and edentulous. Its anterior and posterior ends are obscured

238 and the presence of the basipterygoid process, which would be expected in basal clupeomorphs

239 (Chang and Maisey 2003; Zaragüeta-Bagils 2004; Alvarado-Ortega et al. 2008), is uncertain.

The hyomandibula is large; it has a single head and the shaft appears to be the same width as the head. No other hyopalatine bones are preserved in the fossil; there is fragmentary

242 bone material present in the area where the ectopterygoid and endopterygoid bones would be 243 expected, but details cannot be determined.

247 as impressions. The premaxilla, maxilla, and two supramaxillae comprise the upper jaw. The 248 premaxilla is only partially preserved; it is relatively short and small. The maxilla is a long and 249 curved bone with a longitudinal ridge running at least half the length of the bone. It is very 250 narrow anteriorly with a well-defined head that articulates with the premaxilla and mesethmoid; 251 however, the details of the articulation cannot be determined. From its anterior tip, the maxilla 252 widens as it extends posteriorly to just under the anterior margin of the orbit.

254 large, with a long antero-dorsal process that projects over the smaller anterior supramaxilla. Both 255 supramaxillary bones bear fine longitudinal ridges. 


\section{RH - FOREYCLUPEA FROM NORTHWEST TERRITORIES}

258 There is no evidence of teeth on any of the jaw bones, but this may be an artifact of preservation.

\section{Opercular series and branchial arches}

The opercle is large, with a convex posteroventral margin; it is about twice as high as

262 long. The opercular bone is thickened anteriorly where it contacts the preopercle; just posterior

263 to the robust anterior ridge, there are fine striations in a form of four straight lines along the 264 anterior edge of the opercle. The subopercle is an elongate bone with a rounded ventral margin;

265 the surface of the subopercle is smooth, with no ridges or striations.

266 The preopercle is L-shaped with both limbs well developed; the dorsal limb is slightly

267 longer that the ventral limb. The surface of the bone is smooth. The preopercular sensory canal is 268 enclosed in bone and runs close to the anterior margin of the preopercle, giving off at least six 269 secondary branches. The interopercle is elongate, with a prominent longitudinal groove close to 270 the dorsal margin of the bone.

272 rays are visible below the interopercle but 'clupeoid' projections (McAllister 1968) cannot be

273 distinguished on them. The branchiostegals gradually become wider and more robust from the 274 anterior to the posterior ones.

\section{Vertebral column}

The vertebral column is incompletely preserved and obscured in the specimen and so the total number of vertebrae as well as details of the individual vertebral centra cannot be

279 determined (Fig. 1). Based on the number of ribs and neural spines visible, there are 280 approximately 25 vertebrae present. Abdominal vertebrae are cylindrical, about 1.5 times longer 


\section{RH - FOREYCLUPEA FROM NORTHWEST TERRITORIES}

281 than high. Neural spines associated with the abdominal vertebrae are paired. There are 22 or 23

282 pairs of pleural ribs. The ribs are very long and thin; the anterior ten ribs are curved while the

283 posterior 12 or 13 ribs have a sinuous shape. It is difficult to determine details of the rib

284 articulations in the fossil, but it appears that the anterior-most ribs articulate in deep pits of the

285 abdominal centra.

Intermuscular bones are well developed in the specimen and present in at least two series:

287 epineurals, and epipleurals; epicentral may also be present in the specimen, but due to the poor

288 preservation this cannot be concluded with certainty. The epineurals are associated with all

289 vertebral centra visible; they are thin and long, reaching the length of approximately 2 centra.

290 The epipleurals are shorter than the epineurals; their length is equal to 1.5 vertebral centra.

292 Paired fins and girdles

The pectoral girdle is partially preserved. The posttemporal is present; however, its

294 details cannot be accurately determined. The ventral arm of the posttemporal is expanded and

295 ovoid, but very little can be inferred about the antero-dorsal process of the bone. Just below and

296 posterior to the posttemporal, an elongated supracleithrum is visible; it has been displaced during

297 preservation and appears as a flat and slightly curved bone.

298 The cleithrum is L-shaped, similar to that of Ranulfoichthys dorsonudum (Alvarado-

299 Ortega 2014) and Pseudoellimma gallae (Figueiredo 2009), but with a more slender and pointed

300 dorsal limb (Fig. 3). The ventral limb of the cleithrum is poorly preserved but it appears to be

301 broader then the dorsal limb. There are at least two flat, ovoid postcleithra in the specimen,

302 preserved well behind the cleithrum, that have been displaced posteriorly during preservation.

303 Both postcleithra are broad, unlike the rod-like postcleithra described in some 


\section{RH - FOREYCLUPEA FROM NORTHWEST TERRITORIES}

304

305

306

307

308

309

310

311

312

313

314

315 323 shorter.

ellimmichthyiforms (Armigatus, Diplomystus, and Sorbinichthys) and most clupeiforms; the ventral postcleithrum is slightly elongated and pointed. The right coracoid is preserved overlying the left pectoral fin; it is a subtriangular bone with a convex dorsal margin. The scapula and radials are not preserved in the specimen. The pectoral fin is long, approximately equal to the length of seven abdominal vertebrae. There are 14 pectoral fin rays; the third and fourth rays are the longest in the series.

The pelvic fin is small and positioned anterior to the level of the origin of the dorsal fin (Fig. 1). The pelvic girdle is not preserved in the specimen. Both pelvic fins are visible in the specimen, with a total of12 fin rays preserved; however, the left and right pelvic fins are clumped together and the number of rays in each fin is not clear. Based on the total fin ray counts, there are approximately 6 pelvic fin rays in each.

\section{Median fins}

Only the dorsal fin is preserved in the specimen; it originates approximately above vertebral centrum 20 or 21 . The fin is almost complete but the last few rays are missing due to the partial preservation of the specimen. There are 11 dorsal fin rays preserved; the first two or three are unbranched and the first fin ray is shorter than the following rays. Distal ends of the third and fourth dorsal fin rays are not preserved, making it impossible to determine whether they are branched. Posterior to the fourth ray, the dorsal fin rays are branched and gradually become

The dorsal fin is supported by at least 12 pterygiophores. The first pterygiophore is a large and complex element that appears to be made by the first three bones in the series which 
RH - FOREYCLUPEA FROM NORTHWEST TERRITORIES

326 are connected by a lamina. The anterior ten pterygiophores are long and interdigitate with the

327 neural spines.

\section{Supraneural bones, dorsal and abdominal scutes}

Supraneural bones are for the most part not preserved in the fossil and only the proximal

ends of the bones can be identified. They are long and thin bones without the antero-posterior laminar expansions found in Diplomystus (Grande 1982). The supraneurals interdigitate with the neural spines of the anteriormost vertebrae. The exact number of the supraneural bones cannot be determined; there are two or three bones visible just in front of the dorsal fin in UALVP 17535a and at least three bones close to the occiput in the counterpart of the specimen, UALVP $17535 \mathrm{~b}$. behind the occiput and anterior to the dorsal fin origin, there is no evidence of dorsal scutes. 


\section{RH - FOREYCLUPEA FROM NORTHWEST TERRITORIES}

In the present study, we performed a phylogenetic analysis of the Early Cretaceous

350 (Berriasian - Albian) clupeomorphs with the purpose of clarifying interrelationships and early

diversification patterns within the group. We included 12 fossil clupeomorph taxa from Europe,

Asia, and South and North America that have been assigned to either Ellimmichthyiformes,

(Pseudoellimma gallae and Ranulfoichthys dorsonudum) have never been included before in the phylogenetic analysis of the Clupeomorpha.

The analysis retrieved two most-parsimonious trees that were used to construct a strict consensus tree. The resulting strict consensus tree has a length of 135 steps, a consistency index (CI) of 0.519 , and a retention index of 0.588 (Fig. 4). The bootstrap and Bremer support analyses revealed weak support for most clades (Fig. 4); only one clade (Ellimmichthys longicostatus + E. goodi) had a bootstrap support value higher than $50 \%$. The strict consensus tree contains three polytomies: a basal trichotomy includes a clade consisting of the recent clupeiforms (Odaxothrissa vittata, Chirocentrus dorab, and Denticeps clupeoides), two fossil taxa that have been described as putative clupeiforms (Santanaclupea silvasantosi and Pseudoellimma gallae) and a large group containing ellimmichthyiforms and clupeomorphs of uncertain affinities (Ornategulum sardinoides). Another polytomy within the latter group includes three Early

366 Cretaceous clupeomorphs, Scutatuspinosus itapagipensis, Ranulfoichthys dorsonudum, and 367 Foreyclupea loonensis. The third polytomy is within the Paraclupeidae and includes Ellimmichthys maceioensis, Paraclupea chetungensis, and Triplomystus applegatei. 


\section{RH - FOREYCLUPEA FROM NORTHWEST TERRITORIES}

372 by previous phylogenetic analyses that grouped E. longicostatus and E. goodi as sister-taxa

373 (Zaragüeta-Bagils 2004; Alvarado-Ortega et al. 2008) and revealed E. maceoiensis as being

374 closely related to the Late Cretaceous ellimmichthyiforms Diplomystus solignaci and

375 Rhombichthys intoccabilis (Murray and Wilson 2013). However, none of the previous analyses

376 included all three species of Ellimmichthys to provide a better comparison with the present

377 results.

378

379

380

381

382

The new species, Foreyclupea loonensis, was recovered as a member of a clade that also includes Scutatuspinosus itapagipensis and Ranulfoichthys dorsonudum. This is the first time such a clade has been recovered in a phylogenetic analysis.

\section{Discussion}

Morphological examination of UALVP 17535 provides conclusive evidence that the new species, Foreyclupea loonensis, is a member of the superorder Clupeomorpha: the specimen shows a complete abdominal series of scutes and the supratemporal commissural sensory canal passing through the parietals. The former character has been regarded by many authors as a diagnostic feature exclusive to clupeomorph fishes (Whitehead 1963; Patterson 1970; Grande 1982, 1985; Arratia 1997). Unfortunately, because the specimen is missing its posterior part, no conclusions can be made about the structure of the caudal skeleton. In clupeomorphs, the caudal skeleton is characterized by an autogenous hypural 1 and the second hypural fused to the first ural centrum. These features, although not exclusive to the Clupeomorpha, in combination with other clupeomorph traits provide a reliable diagnosis for the group.

Along with the general clupeomorph characteristics mentioned above, Foreyclupea loonensis shows a mosaic of primitive and derived features that make further classification of the 


\section{RH - FOREYCLUPEA FROM NORTHWEST TERRITORIES}

395 396

new taxon within the Clupeomorpha problematic. The cranial skeleton of $F$. loonensis shows the following plesiomorphic conditions: parietals contacting each other in the midline and absence of the recessus lateralis.

The parietal bones contacting each other medially (medioparietal condition of the skull roof) is a common plesiomorphic condition present in ellimmichthyiforms and many other groups of teleost fishes including ichthyodectiforms, osteoglossomorphs, elopiforms, salmoniforms and others (Grande, 1985; Arratia, 1997). Grande (1985) used this character to separate non-clupeiform clupeomorphs from more derived members of the order Clupeiformes that have parietals completely separated by the supraoccipital (lateroparietal condition). Presence of the recessus lateralis is a highly diagnostic character exclusive to all extant members of the Clupeomorpha (equivalent to the order Clupeiformes). The evolutionary pattern of this character distribution within the group corresponds to the subdivision of the Clupeomorpha into two orders: Clupeiformes with a recessus lateralis and Ellimmichthyiformes without it. In the fossil taxa, presence of a recessus lateralis can be inferred from the reduced size of the dermosphenotic that does not carry the infraorbital sensory canal (Forey 1975; Grande 1985) and perforation of the pterotic with the openings for the cephalic sensory canals (Patterson 1970; Maisey 1993; Di Dario 2002). The dermosphenotic is missing in the studied specimen, but the preserved portion of the pterotic bone does not show any openings for the sensory canals; this may indicate that a recessus lateralis was primitively absent in the fish.

Foreyclupea loonensis also shows unfused neural spines of the abdominal vertebrae. This is a primitive condition that has been recognized in many teleost groups (Arratia 1997). Among the clupeomorphs, paired neural spines are present in the basal Early Cretaceous fossil taxa 


\section{RH - FOREYCLUPEA FROM NORTHWEST TERRITORIES}

417 Ranulfoichthys dorsonudum, Santanaclupea silvasantosi, Pseudoellimma gallae, and members

418 of the Late Cretaceous genus Armigatus.

The new species is distinguished from other ellimmichthyiforms by the following combination of derived characters: loss of the predorsal series of scutes, presence of at least two broad postcleithra, and position of the pelvic fin anterior to the origin of the dorsal fin. Some of

422 these features also occur in Scutatuspinosus and Ranulfoichthys, basal clupeomorphs of unresolved affinities. These characteristics suggest that Foreyclupea loonensis is a new taxon of

424 primitive clupeomorph with close affinities to the known species of the ellimmichthyiforms. This

425 conclusion is also supported by the results of the present phylogenetic analysis. groups with unresolved phylogenetic relationships: the recent clupeiforms (Chirocentrus dorab, including Ornategulum sardinoides.

The recent clupeiforms as well as the two putative fossil clupeiform taxa, Barremian

432 Pseudoellimma gallae from the brackish deposits of the Coqueiro Seco Formation, Brazil, and

433 the middle/late Albian Santanaclupea silvasantosi from the black shales of the Santana

434 Formation, Brazil, are distinguished from the ellimmichthyiforms by the parietals completely 435 separated by the supraoccipital $(2: 1)$ and presence of the recessus lateralis $(8: 1)$. However, the 436 early clupeomorphs (Pseudoellimma gallae and Santanaclupea silvasantosi) also show some 437 primitive characteristics also present in the ellimmichthyiforms-Santanaclupea has the 438 'beryciform' foramen in the anterior ceratohyal (this condition is unknown in Pseudoellimma 439 due to the missing ceratohyal elements); Pseudoellimma shares the following characters with 


\section{RH - FOREYCLUPEA FROM NORTHWEST TERRITORIES}

440 ellimmichthyiforms: long and lanceolate neural spine of the first preural centrum (44:0),

441 subrectangular scutes in the posterior part of the predorsal series (49:1). Both taxa also

442 primitively retain hypural 1 in contact with the first ural centrum (28:0); in derived clupeiforms,

443 hypural 1 is separated from the first ural centrum by a gap (Grande 1985; Chang and Maisey 444 2003).

In a strict consensus tree (Fig. 4), recent clupeiforms and fossil clupeomorphs

446 (Santanaclupea + Pseudoellimma) form a trichotomy with a large clade of fossil non-clupeiform

447 clupeomorphs. Members of this clade are different from the clupeiforms in having parietals

448 contacting each other in the midline (2:0), lacking a recessus lateralis (8:0). This group also

449 includes a problematic clupeomorph taxon, Ornategulum sardinoides; however, phylogenetic

450 placement of this taxon requires further investigation that is beyond the scope of this study. In

451 addition to the mentioned above characteristics (absence of the recessus lateralis and parietals

452 contacting each other in the midline), fossil non-clupeiform clupeomorphs are characterized by

453 having the anteriormost pleural ribs articulate with deep pits on the lateral side of abdominal

454 centra and those located posteriorly articulate with well-developed parapophyses (19:1). The first

455 two characteristics (medioparietal condition of the skull roof and absence of recessus lateralis)

456 have been attributed to the ellimmichthyiforms (Grande 1985). Grande $(1982,1985)$ and

457 Alvarado-Ortega et al. (2008) also recognized the presence of subrectangular predorsal scutes as

458 a synapomorphy of the ellimmichthyiforms; however, this character was questioned by Chang

459 and Maisey (2003) as being a reliable diagnostic feature of the order. The latter authors noted

460 that due to the variability in the scute shape within the Ellimmichthyiformes, it is necessary to

461 reevaluate the shape of the dorsal scutes as a single character supporting monophyly of the order.

462 This large clade of non-clupeiform clupeomorphs includes two major groups: a clade containing 


\section{RH - FOREYCLUPEA FROM NORTHWEST TERRITORIES}

the Neocomian (Valanginian - Barremian) Scutatuspinosus itapagipensis from Brazil, and the early/middle Albian Ranulfoichthys dorsonudum and Foreyclupea loonensis from Mexico and Canada respectively as a sister group to a clade of all ellimmichthyiform taxa included in the analysis: (Ezkutuberezi carmeni $+($ Paraclupea chetungensis $+($ Ellimma branneri + Ellimmichthys maceoiensis + Triplomystus applegatei $)+($ Ellimmichthys longicostatus + Ellimmichthys goodi)).

The clade (Scutatuspinosus + Ranulfoichthys + Foreyclupea $)$ includes primitive clupeomorphs of uncertain affinities. Members of this group have torpedo-shaped body with a smooth and slightly rounded anterior dorsal margin of the body (1:0), abdominal scutes with short ascending lateral 'arms' (58:0), and a homoplastic character — absence of a diastema between hypurals 2 and 3 (31:1, this feature also occurs in the ellimmichthyiform genera Armigatus and Diplomystus). We here adopt Scutatuspinosidae (new rank, formerly subfamily Scutatospinosinae Silva Santos and Silva Correa, 1985, with type genus Scutatospinosus) as a name for this clade.

Unlike any other ellimmichthyiform species, Ranulfoichthys dorsonudum and Foreyclupea loonensis do not have a predorsal series of scutes; however, a complete series of predorsal scutes is present in Scutatuspinosus, the oldest member of the clade. This finding supports the idea that presence of a predorsal series of scutes is a primitive characteristic within the Clupeomorpha that is retained by some living members of the Clupeiformes. Foreyclupea and Ranulfoichthys share at least one more characteristic unique among the ellimmichthyiforms - presence of at least two expanded postcleithra. Grande (1985) regarded presence of two rod-shaped postcleithra as a diagnostic character for the Clupeidae; since then, long, rodlike postcleithra have been described in some ellimmichthyiforms: Armigatus (Forey et 


\section{RH - FOREYCLUPEA FROM NORTHWEST TERRITORIES}

486

487

488

489

490

491

492

493

494

495

496

497

498

499

500

501

502

503

504

505

506

507

508

al. 2003), Diplomystus (pers.obs.UALVP 17731, 21163, 22860), Thorectichthys (Murray and Wilson 2013), Horseshoeichthys (Newbrey et al. 2010), and Tycheroichthys (Hay et al. 2007).

Grande (1985) also noted that, in some clupeids, postcleithra can be moderately to broadly expanded; however, this condition is not known in any ellimmichthyiform species.

Foreyclupea and Ranulfoichthys each share unique characteristics with Scutatuspinosus.

Ranulfoichthys and Scutatuspinosus have a unique morphology of the ascending lateral 'arms' of the abdominal scutes - each ventral scute has very short, broad and subrectangular lateral wings. This condition is different from the spine-like ascending processes of the abdominal scutes observed in the extinct and Recent clupeomorphs (Armigatus, Diplomystus, Sorbinichthys, Thorectichthys, Ellimmichthys, Clupeidae, Pristigasteridae) or the long spatula-like ascending arms of abdominal scutes in ellimmichthyiform genera Triplomystus, Tycheroichthys, and Rhombichthys.

For Foreyclupea and Scutatuspinosus, position of the pelvic fin anterior to the level of the origin of the dorsal fin is recognized as a shared derived characteristic. This position of the pelvic fin is not common among the ellimmichthyiforms or Recent clupeiforms and is considered to be a derived feature among teleost fishes. Chang and Maisey (2003) also noted that the pelvic fin is inserted in advance of the dorsal fin origin in Ellimmichthys longicostatus.

Another major group retrieved by the phylogenetic analysis contains all previously recognized Early Cretaceous ellimmichthyiform taxa that have been included in the analysis; it most closely corresponds to the family Paraclupeidae sensu Alvarado-Ortega et al. (2008) and Murray and Wilson (2013). Grouping of these taxa in the analysis is supported by the following characteristics: straight ascending dorsal margin of the body that forms a distinct angle at the insertion of the dorsal fin $(1: 1)$, fused neural arches and spines of abdominal vertebrae (18:1), S- 


\section{RH - FOREYCLUPEA FROM NORTHWEST TERRITORIES}

509

510

511

512

513

514

515

516

517

518

519

520

521

522

523

524

525

526

527

528

529

530

531

shaped cleithrum (22:1), and large lateral spines of the abdominal scutes (58:1). Within this group of ellimmichthyiforms, Ezkutuberezi carmeni from the Valanginian-Barremian of Spain

appears as the most basal taxon; other ellimmichthyiform taxa were recovered in a sister group to Ezkutuberezi with two species of Ellimmichthys (E. longicosatus and E. goodi) forming a wellsupported clade characterized by the broad distal end of hypural 2 (30:0), dorsal laminar expansion of the first uroneural (37:1), and increased number of predorsal scutes (54:2). Overall, the results of the phylogenetic analysis of the Early Cretaceous clupeomorphs suggest that the clupeiforms and ellimmichthyiforms diverged in the early Early Cretaceous and formed separate lineages as early as in the Barremian (with the clupeiform Pseudoellimma gallae from Brazil, as well as the ellimmichthyiforms Ezkutuberezi carmenae from Spain, and

Scutatuspinosus itapagipensis from Brazil). It is also worth noting that the oldest clupeomorphs, described from the Berriasian-Barremian, are known predominantly from freshwater and estuarine environments; this includes the Neocomian (Valanginian-Barremian) Scutatuspinosus itapagipensis from the lacustrine sediments of Reconcavo Basin, Brazil, Ellimmichthys longicostatus (Cope 1886) from the late Hauterivian - early Barremian estuarine deposits of the Marfim Formation, Brazil, Ezkutuberezi carmenae Poyato-Ariza et al., 2000, from the Valanginian-Barremian deltaic and lacustrine deposits of the Villaro Formation, Spain; and Pseudoellimma gallae from the Barremian brackish water deposits of the Coqueiro Seco Formation, Brazil. The evolutionary significance of this pattern is yet not clear but it may shed light on the origins of the diadromous behavior of some clupeomorphs as well as provide valuable information on the evolution of the osmoregulatory system in these fishes. It is clear that knowledge of the earliest members of the Clupeomorpha is crucial to our understanding of the complex evolutionary patterns of clupeomorph ecology and biogeography. 
RH - FOREYCLUPEA FROM NORTHWEST TERRITORIES

533 Summary

The evolutionary history of the Clupeomorpha remains an unresolved issue. Major questions persist about clupeomorph origins, diversification between clupeiforms and

536 ellimmichthyiforms, and biogeographic dynamics of these fishes. The early fossil record of 537 clupeomorphs provides some valuable clues to these questions. Foreyclupea loonensis, gen. et 538 sp. nov., is the oldest clupeomorph fossil described from Canada. Based on the primitive cranial 539 characteristics (parietals contacting each other in the midline and absence of the recessus lateralis), the new species is classified as a member of the Ellimmichthyiformes. Foreyclupea

541 loonensis is a remarkable taxon in showing a number of derived characteristics (absence of 542 dorsal scutes, pelvic fin insertion anterior to the origin of the dorsal fin, and presence of at least 543 two broad postcleithra) that distinguish it from other ellimmichthyiforms. Together with other 544 primitive clupeomorphs from the Neocomian deposits of Brazil (Scutatuspinosus) and Albian of 545 Mexico (Ranulfoichthys), the new species forms a clade of torpedo-bodied fishes. This clade 546 supports Grande's (1985) idea of the evolutionary pattern of the predorsal series of scutes in the 547 clupeomorphs - a complete series of predorsal scutes is a primitive condition in clupeomorphs 548 that precedes the loss of this feature in multiple lineages.

\section{Acknowledgements}

551 We thank Mr. Alan Lindoe, who collected and prepared the fossil material. We are grateful to

552 Dr. Peter L. Forey who first described the fossils. We also want to thank our editors and

553 reviewers, Jesus Alvarado-Ortega and Gloria Arratia, for their valuable comments and

554 suggestions that helped improve the manuscript. This research was supported by Natural 


\section{RH - FOREYCLUPEA FROM NORTHWEST TERRITORIES}

555 Sciences and Engineering Research Council of Canada Discovery Grants 327448 (A.M.M.). 
RH - FOREYCLUPEA FROM NORTHWEST TERRITORIES

\section{References}

557 Alvarado-Ortega, J. 2014. Ancient herring from the Tlayúa Quarry (Cretaceous, Albian) near

558 Tepexi de Rodíguez, Puebla State, central Mexico, closing the gap in the early

Alvarado-Ortega, J., and Ovalles-Damiän,E. 2008. Triplomystus applegatei, sp.nov. (Teleostei: Ellimmichthyiformes), a rare "triple armored herring” from El Espinal Quarry (Early Cretaceous), Chiapas, southeastern Mexico. Journal of Vertebrate Paleontology, 28: 5360.

Alvarado-Ortega, J., Ovalles-Damiàn, E., and Arratia,G. 2008. A review of the interralationships of the order Ellimmichthyiformes (Teleostei: Clupeomorpha). In Mesozoic fishes 4 homology and phylogeny. Edited byG. Arratia, H.-P.Schultze, and M.V.H.Wilson. Verlag Dr. FriederichPfeil, Münich, Germany, pp. 257-278.

Arratia, G. 1997. Basal teleosts and teleostean phylogeny. PalaeoIchthyologica, 7: 1-168.

Blainville, H. de. 1818. Sur les ichthyolites, ou les poisons fossils. Nouveau Dictionnaire d'HistoireNaturelle, Appliquée aux Arts, à l'Agriculture , à l'Économierurale et domestique, à la Médecine, etc., 27: 310-395.

Chang, M.-M., and Grande, L. 1997. Redescription of Paraclupea chetungensis, an Early Cretaceous clupeomorph from the Lower Cretaceous of southeastern China. Fieldiana, Geology, 37 (1489): 1-19.

Chang, M.-M., and Maisey, J. 2003. Redescription of Ellimma branneri and Diplomystus shengliensis, and relationships of some basal clupeomorphs. American Museum Novitates, 3404: 1-35. 


\section{RH - FOREYCLUPEA FROM NORTHWEST TERRITORIES}

578

579

580

581

582

583

584

585

586

587

588

589

590

591

592

593

594

595

596

597

598

599

600

Cope, E. D. 1877. A contribution to the knowledge of the ichthyological fauna of the Green River Shales. Bulletin of United States Geological and Geographical Survey, 3:807819.

Cope, E. D. 1886. A contribution to the vertebrate paleontology of Brazil. Proceedings of the American Philosophical Society, 23 (121): 3-4.

Di Dario, F. 2002. Evidence supporting a sister-group relationship between Clupeoidea and Engrauloidea (Clupeomorpha). Copeia: 496-503.

Eastman, C. R. 1912. Tertiary fish-remains form Spanish Guinea in West Africa. Annals of the Carnegie Museum, 8: 370-378.

Figueiredo, F .J. 2009.A new Clupeiform fish from the Lower Cretaceous (Barremian) of Sergipe-Alagoas Basin, northeastern Brazil. Journal of Vertebrate Paleontology, 29: 993-1005.

Forey, P. L. 1975. A fossil clupeomorph fish from the Albian of the Northwest Territories of Canada, with notes on cladistic relationships of clupeomorphs. Journal of Zoology, London, 175: 151-177.

Forey, P. L., Yi,L., Patterson,C., and Davies,C. E. 2003. Fossil fishes from the Cenomanian (Upper Cretaceous) of Namoura, Lebanon. Journal of Systematic Palaeontology, 1: 227-330.

Forsskål, P. S. 1775. Descriptionesanimalium, avium, amphibiorum, piscium, insectorum, vermium; quae in itinereorientaliobservavit.Post mortem auctorisedidit Carsten Niebuhr. Havenai, Mölleri.

Goloboff, P., Farris, S.,and Nixon,K. 2008. TNT, a free program for phylogenetic analysis. Cladistics, 24: 774-786. 
RH - FOREYCLUPEA FROM NORTHWEST TERRITORIES

601 602 603 604 605 606 607 608 609 610 611 612 613 614 615 616 617 618 619 620 621 622

Grande, L. 1982. A revision of the fossil genus Diplomystus, with comments on the interrelationships of clupeomorph fishes. American Museum Novitates, 2728: 1-34.

Grande, L. 1985. Recent and fossil clupeomorph fishes, with materials for the revision of the subgroups of clupeoids. Bulletin of the American Museum of Natural History, 181: $231-372$.

Greenwood, P. H., Rosen, D.E., Weitzman, S.H., and Myers,G.S. 1966. Phyletic studies of teleostean fishes, with a provisional classification of living forms. Bulletin of the American Museum of Natural History, 131: 339-456.

Hathway, B., Dolby, G., McNeil, D. H., Kamo, S. L., Heizler, M. T., and Joyce, N. 2013. Revised stratigraphy, regional correlations and new bentonite radiometric ages for the Albian Loon River Formation, Fort St. John Group, northwestern Alberta. Bulletin of Canadian Petroleum Geology, 61 (4): 331-358.

Hay, M. J., Cumbaa, S. L., Murray, A. M., and Plint, A. G. 2007. A new paraclupeid fish (Clupeomorpha, Ellimmichthyiformes) from a muddy marine prodelta environment: middle Cenomanian Dunvegan Formation, Alberta, Canada. Canadian Journal of Earth Sciences, 44: 775-790.

Hermus, C. R., Wilson, M. V. H., and Macrae, A. 2004.A new species of the Cretaceous teleostean fish Erichalcis from Arctic Canada, with a revised diagnosis of the genus. In Mesozoic Fishes 3 - systematics, paleoenvironments and biodiversity. Edited by G. Arratia and A. Tintori.Verlag Dr. FriederichPfeil, Münich, Germany,pp. 449-461.

Jordan, D. S. 1910. Description of a collection of fossil fishes from the bituminous shales at Riaco Doce, state of Alaqôas, Brazil. Annals of the Carnegie Museum, 7: 23-24. 
RH - FOREYCLUPEA FROM NORTHWEST TERRITORIES

623 Lesueur, C. A. 1818. Description of several new species of North American fishes (continued).

624

625

626

627

628

629

630

631

632

633

634

635

636

637

638

639

640

641

642

643

644 Journal of Academy of Natural Sciences, 1: 359-369.

Maddison, W. P., and Maddison, D. R. 2011. Mesquite: a modular system for evolutionary analysis. Version 2.75. http://mesquiteproject.org

Maisey, J. G. 1993. A new clupeomorph fish from the Santana Formation (Albian) of NE Brazil. American Museum Novitates, 3076: 1-15.

Malabarba, M. C., do Carmo,D. A., Gómez-Pérez, I., and de Queiroz-Neto,J. V. 2004. A new clupeomorph fish from the Cretaceous Maceió Formation, Alagoas Basin, NE Brazil. Neues Jahrbuck für Geologie und Paläontologie - Abhandlungen, 233: 255-274.

Maxwell, E. E., and Caldwell, M. W. 2006. A new genus of ichthyosaur from the Lower Cretaceous of Western Canada. Palaeontology, 49: 1043-1052.

McAllister, D. E. 1968. Evolution of branchiostegals and classification of teleostome fishes. Bulletin of the National Museum (Canada), 221: 1-239.

Müller, J. 1845. Über den Bau und die Grenzen der Ganoiden und über das natürlichen System der Fische. Archiv für Naturgeschichte, 11: 91-141.

Murray, A. M., and Wilson, M. V. H. 2011. A new species of Sorbinichthys (Teleostei: Clupeomorpha: Ellimmichthyiformes) from the Late Cretaceous of Morocco. Canadian Journal of Earth Sciences, 48: 1-9.

Murray, A. M., and Wilson, M. V. H. 2013. Two new paraclupeid fishes (Clupeomorpha: Ellimmichthyiformes) from the Late Cretaceous of Morocco. In Mesozoic Fishes 5global diversity and evolution. Edited by G. Arratia, H.-P. Schultze, and M. V. H. Wilson. Verlag Dr. Friederich Pfeil, Munich, Germany, pp. 267-290. 
RH - FOREYCLUPEA FROM NORTHWEST TERRITORIES

645 Newbrey, M. G., Murray, A. M., Brinkman, D. B., Wilson, M. V. H., and Neuman, A. G. 2010.

646

647

648

649

650

651

652

653

654

655

656

657

658

659

660

661

662

663

664

665

666

A new articulated freshwater fish (Clupeomorpha, Ellimmichthyiformes) from the

Horseshoe Canyon Formation, Maastrichtian, of Alberta, Canada. Canadian Journal of Earth Sciences, 47: 1183-1196.

Patterson, C. 1970. A clupeomorph fish from the Gault (Lower Cretaceous). Zoological Journal of the Linnean Society of London, 49 (3): 161-182.

Patterson, C., and Rosen, D.E. 1977. Review of ichthyodectiform and other Mesozoic teleost fishes and the theory and practice of classifying fossils. Bulletin of the American Museum of Natural History, 158: 83-172.

Poyato-Ariza, F. J., López-Horgue, M. A., Garcia-Garmilla, M. A., and Garcia-Garmilla, F. 2000. A new Early Cretaceous clupeomorph fish from the Arratia Valley, Basque Country, Spain. Cretaceous Research, 21 (4): 571-585.

Rudkin, R. A. 1964. Lower Cretaceous. In Geologic History of Western Canada. Edited by R. G. McCrossan and R. P. Glaister. Alberta Society of Petroleum Geologists, Calgary, Canada, pp. 156-168.

Singh, C. 1971. Lower Cretaceous microfloras of the Peace River area, northwestern Alberta. Bulletin of the Research Council of Alberta, 28: 1-542.

Silva Santos, R., and Silva Corréa, V. L. 1985. Contribuição ao conhecimento da paléoictiofaunula do Cretáceo no Brasil. In Coletánea de Trabalhos Paleontológicos, Série Geologia. Edited by A. de Campos, C. S. Ferreira, I. M. Brito, and C. F. Viana. Ministério das Minas e Energia-DepartamentoNacional de Produção Mineral, Rio de Janeiro, Brazil, pp. 169-174. 
RH - FOREYCLUPEA FROM NORTHWEST TERRITORIES

667 Sun, A.-L. 1956. Paraclupea - A genus of double-armoured herrings from Chekiang. Acta

$668 \quad$ Palaeontologica Sinica, 4: 413-418.

669 Taverne, L. 2002. Les poissons crétacés de Nardò. $12^{\circ}$. Nardoclupea grandei gen. et sp. nov.

670 (Teleostei, Clupeiformes, Dussimieriinae). Bollettino del Museo Civico di Storia

671 Naturale di Verona, Geologia, Paleontologia, Preistoria 26: 3-23.

672 Whitehead, P. J. P. 1963. A contribution to the classification of clupeoid fishes. Annals and

673 Magazine of Natural History, 5: 737-750.

674 Wilson, A. 1811.Clupea Heading. In Reese's New Cyclopedia. American edition. Vol. 9, Part 1.

675 Zaragüeta-Bagils, R. 2004. Basal clupeomorphs and ellimmichthyiform phylogeny. In Mesozoic

676 Fishes 3 - systematics, paleoenvironments and biodiversity. Edited by G. Arratia and

677 A. Tintori. Verlag Dr. Friederich Pfeil, Münich, Germany, pp. 391-404.

678

679 
RH - FOREYCLUPEA FROM NORTHWEST TERRITORIES

\section{FIGURE CAPTIONS}

Figure 1. Foreyclupea loonensis, gen. et sp. nov.; A, photograph of the holotype, UALVP 17535a; B, line drawing of the specimen UALVP 17535a. Abbreviations: abds, abdominal scutes; epl, epipleural; epn, epineural; pcl 1-2, postcleithra 1-2; pcl2 (1), left postcleithrum 2; sn, supraneural bones; scl, supracleithrum. Scale bars $=5 \mathrm{~mm}$.

Figure 2. Reconstruction of Foreyclupea loonensis, gen et sp. nov. Scale bar $=5 \mathrm{~mm}$.

Figure 3. Foreyclupea loonensis, gen. et sp. nov. A, photograph of the head of the holotype, UALVP 17535a; B, restoration of the head in right lateral view. Abbreviations: br, branchiostegal rays; cl, cleithrum; cor, coracoid; fr, frontal bones; hyo, hyomandibular; io3, infraorbital 3; iop, interopercle; le, lateral ethmoid; mes, mesethmoid; mx, maxilla; op, opercle; pa, parietal; pcl 1-2, postcleithra 1-2; pmx, premaxilla; pop, preopercula; ps, parasphenoid; pto, pterotic; ptt, posttemporal; r, rib; scl, supracleithrum; soc, supraoccipital; sop, subopercle; smx 1-2, supramaxillae 1-2. Scale bar $=5 \mathrm{~mm}$

Figure 4. Results of the phylogenetic analysis of the Early Cretaceous clupeomorphs including Foreyclupea loonensis, gen. et sp. nov. A strict consensus of the two most-parsimonious trees (tree length $=155$ steps, $\mathrm{CI}=0.519, \mathrm{RI}=0.588)$. Bootstrap support values that are higher than $50 \%$ are shown above the branches. 
TABLE 1. Counts and measurements of Foreyclupea loonensis, sp. et gen. nov.specimen UALVP 17535. All measurements are in mm.

\begin{tabular}{|l|l|}
\hline & 13575 \\
Characteristic & \\
\hline Standard length (SL) & \\
\hline Head length & $?$ \\
\hline Head depth & 15 \\
\hline Greatest body depth & 19 \\
\hline Predorsal length & 42 \\
\hline Prepelvic length & 40 \\
\hline Preanal length & $?$ \\
\hline Dorsal fin rays & $? 11$ \\
\hline Pectoral fin rays & 14 \\
\hline Pelvic fin rays & $? 6$ \\
\hline Abdominal vertebrae & $22-23$ \\
\hline Predorsal bones & $?$ \\
\hline Abdominal scutes & $? 19$ \\
\hline Pre-pelvic scutes & 13 \\
\hline Post-pelvic scutes & 6 \\
\hline Pre-dorsal scutes & - \\
\hline Pairs of ribs & 18 \\
\hline
\end{tabular}




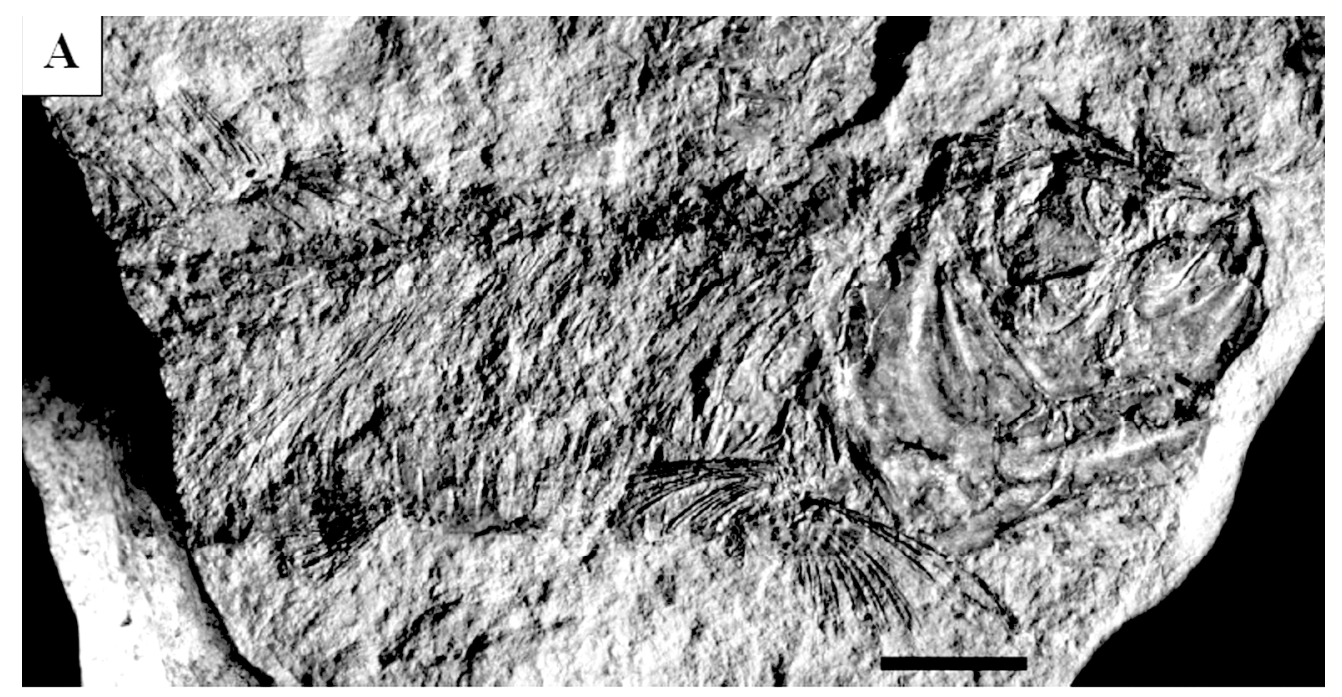

B

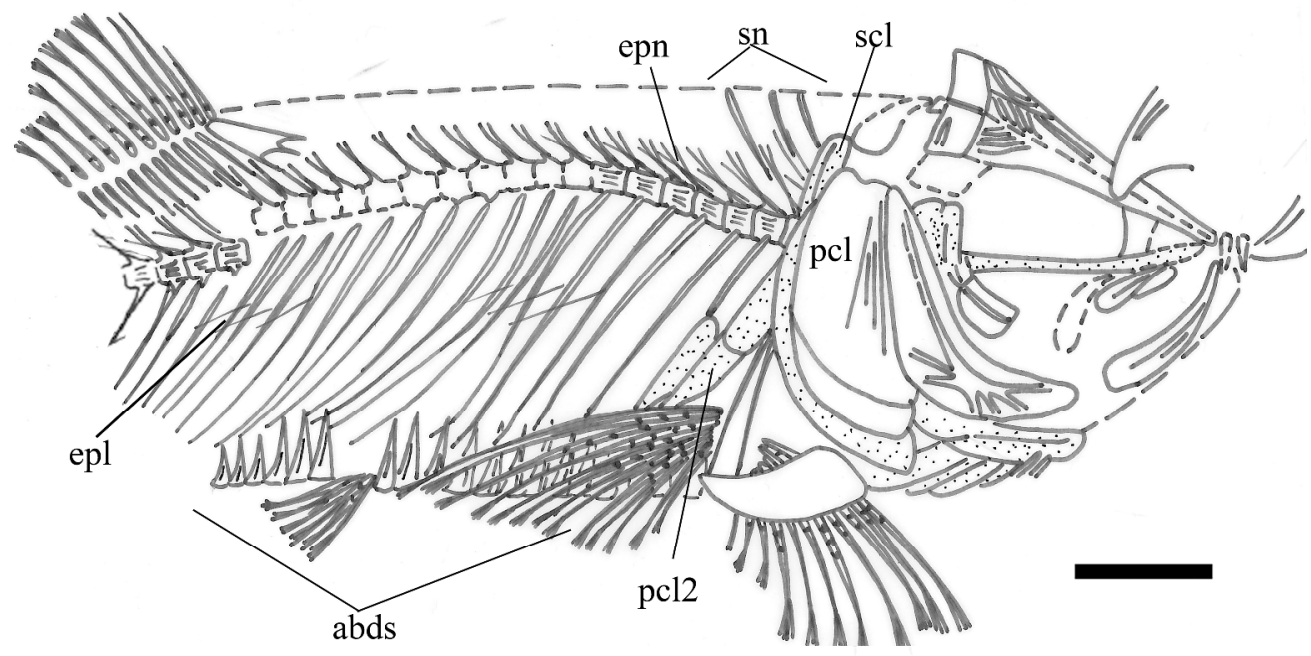

Figure 1. Foreyclupea loonensis, gen. et sp. nov.; A, photograph of the holotype, UALVP 17535a; B, line drawing of the specimen UALVP 17535a. Abbreviations: abds, abdominal scutes; epl, epipleural; epn, epineural; pcl 1-2, postcleithra 1-2; pcl2 (I), left postcleithrum 2; sn, supraneural bones; scl, supracleithrum. Scale bars $=5 \mathrm{~mm}$.

$1516 \times 1729 \mathrm{~mm}(72 \times 72 \mathrm{DPI})$ 


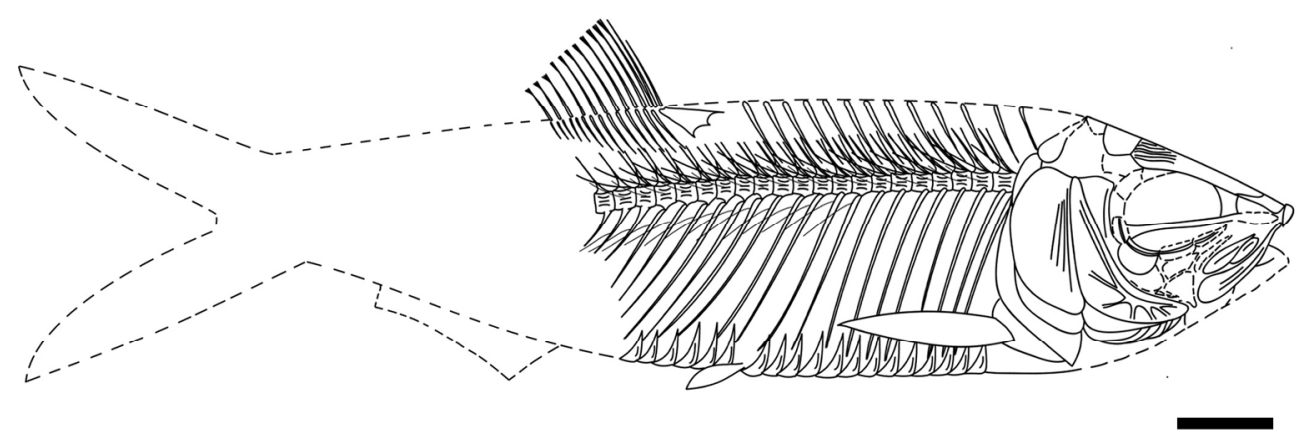

Reconstruction of Foreyclupea loonensis, gen et sp. nov. Scale bar $=5 \mathrm{~mm}$. $758 \times 273 \mathrm{~mm}(72 \times 72 \mathrm{DPI})$ 

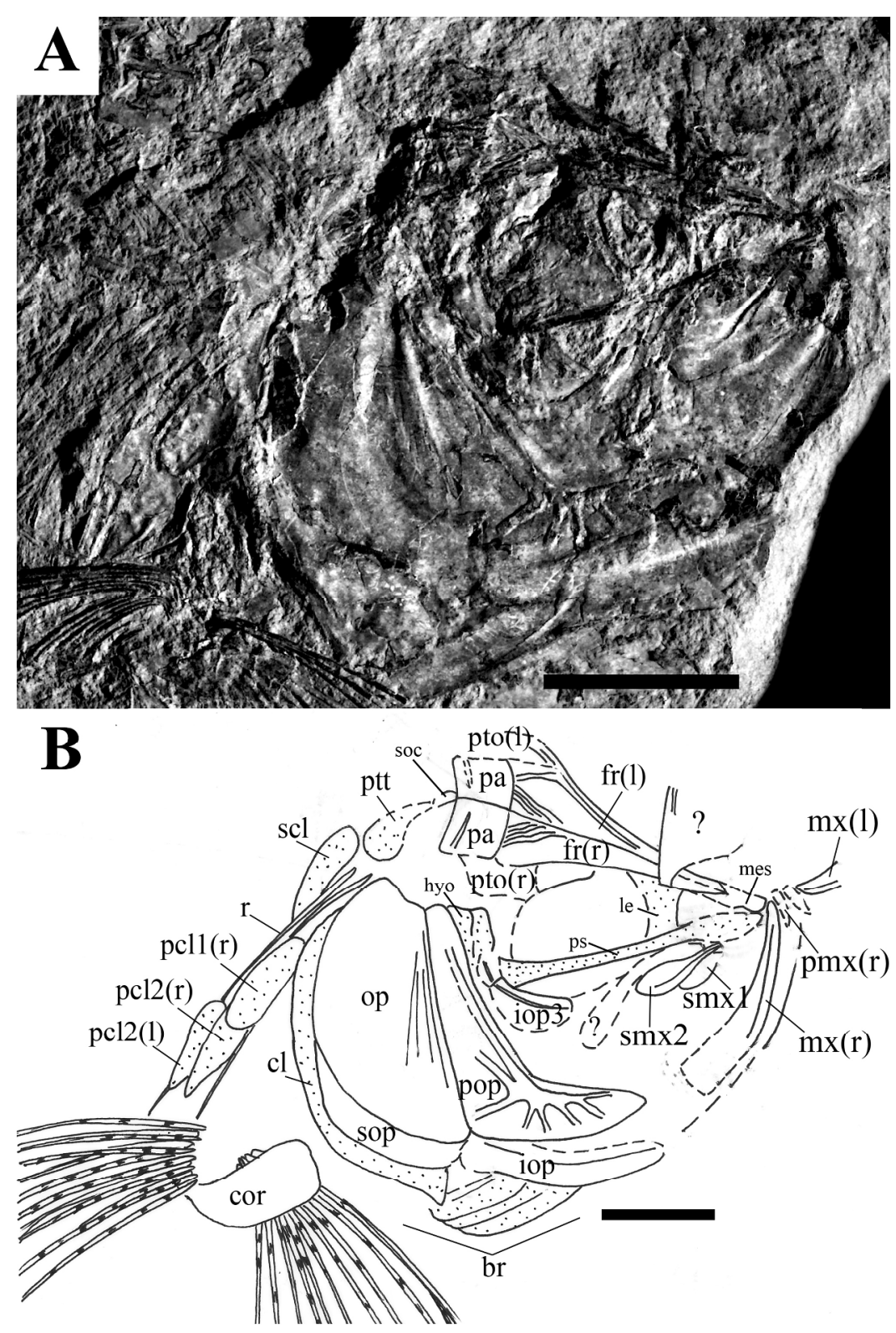

Foreyclupea loonensis, gen. et sp. nov. A, photograph of the head of the holotype, UALVP 17535a; B, restoration of the head in right lateral view. Abbreviations: br, branchiostegal rays; cl, cleithrum; cor, coracoid; fr, frontal bones; hyo, hyomandibular; io3, infraorbital 3; iop, interopercle; le, lateral ethmoid; mes, mesethmoid; mx, maxilla; op, opercle; pa, parietal; pcl 1-2, postcleithra 1-2; pmx, premaxilla; pop, preopercula; ps, parasphenoid; pto, pterotic; ptt, posttemporal; r, rib; scl, supracleithrum; soc, supraoccipital; sop, subopercle; smx 1-2, supramaxillae 1-2. Scale bar $=5 \mathrm{~mm}$ $716 \times 1069 \mathrm{~mm}$ (72 x 72 DPI) 


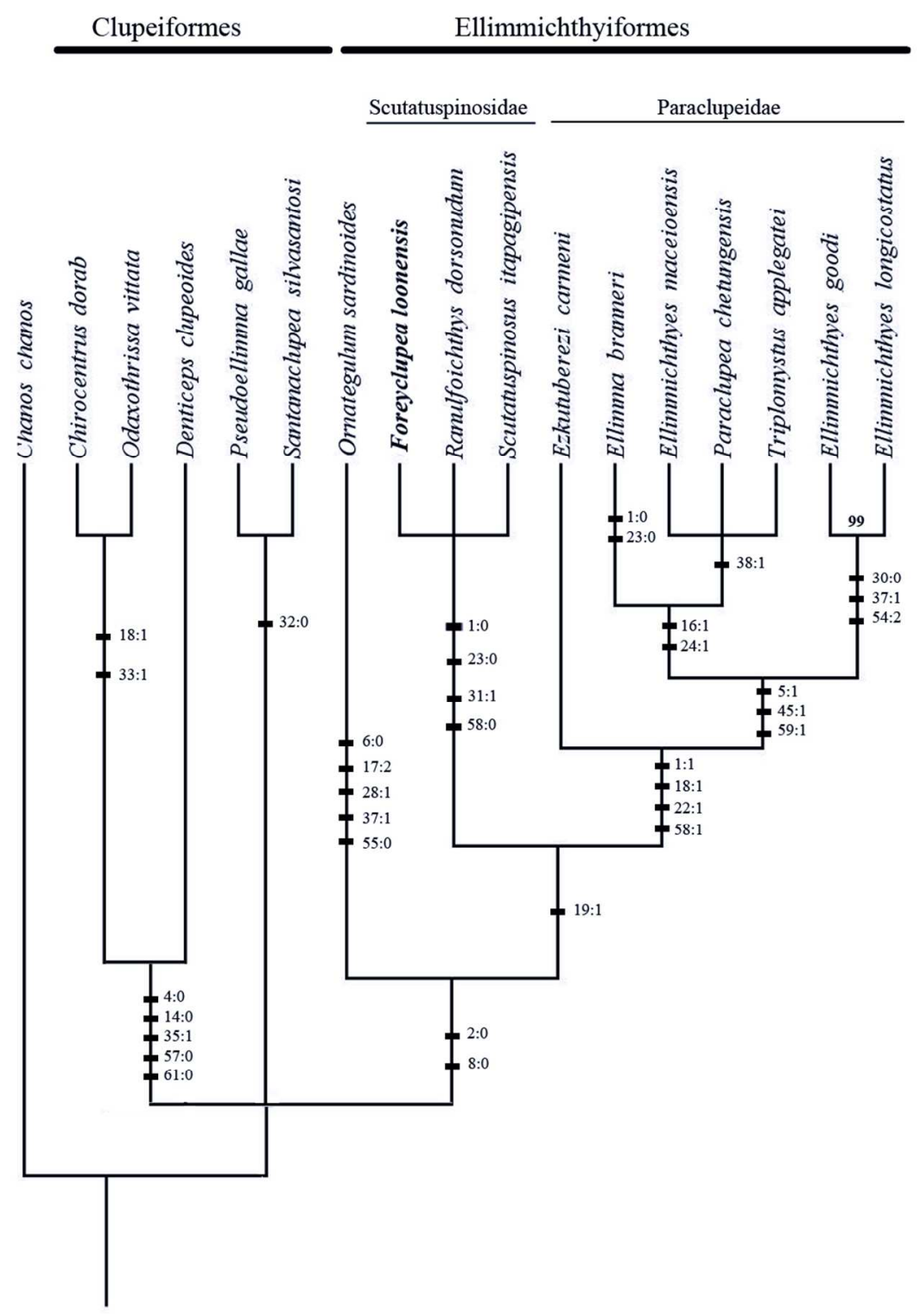

Results of the phylogenetic analysis of the Early Cretaceous clupeomorphs including Foreyclupea loonensis, gen. et sp. nov. A strict consensus of the two most-parsimonious trees (tree length $=155 \mathrm{steps}, \mathrm{CI}=$ 0.519 , RI $=0.588)$. Bootstrap support values that are higher than $50 \%$ are shown above the branches. $397 \times 519 \mathrm{~mm}(72 \times 72$ DPI $)$ 


\section{RH - FOREYCLUPEA FROM NORTHWEST TERRITORIES}

APPENDIX 1. Character state list used in the phylogenetic analysis based on Murray and Wilson (2013):

1. Anterior dorsal margin of body: [0] rounded and convex; [1] almost straight, forming a marked angle at the dorsal fin insertion.

2. Skull roof: [0] parietals bones contacting each other in the midline; [1] supraoccipital separates parietal bones.

3. Lateral profile of skull roof: [0] a straight line from anterior tip of frontal to back of skull, with no distinct angle apparent; [1] with distinct angle between anterior and posterior parts, normally in the region of the parietal.

4. Ornamentation of skull roof bones: [0] absent; [1] present.

5. Ornamentation of skull roof bones: [0] fine, more or less parallel grooves; [1] strong grooves with numerous fine, radiating ridges.

6. Posttemporal fossa: [0] absent; [1] present.

7. Cavity in the temporal region of the skull: [0] pre-epioccipital fossa (between parietal, epioccipital and pterotic bones); [1] pre-epioccipital fenestra (between the parietal, epioccipital and supraoccipital bones); [2] absence of cavity or fenestra.

8. Recessus lateralis: [0] absent; [1] present.

9. Supramaxillary bones: [0] two; [1] one or none.

10. 'Basipterygoid' process of parasphenoid: [0] absent; [1] present.

11. 'Osteoglossid' tooth patch on the parasphenoid: [0] absent; [1] present.

12. Supraorbital bone: [0] absent; [1] present.

13. Antorbital bone: [0] absent; [1] present.

14. Beryciform foramen within the anterior ceratohyal: [0] absent; [1] present.

15. Foramen in posterior ceratohyal: [0] absent; [1] present.

16. Teeth on endopterygoid: [0] absent; [1] present.

17. Total number of vertebrae excluding uralcentra: [0] 30-40; [1] 41-43; [2] more than 50. 


\section{RH - FOREYCLUPEA FROM NORTHWEST TERRITORIES}

18. Halves of the neural arches of most abdominal vertebrae: [0] separate medially; [1] fused medially.

19. Pleural ribs: [0] all ribs articulate with parapophyses along the abdominal region; [1] anteriormost ribs articulate with deep pits on the lateral side of all abdominal centra and those located posteriorly articulate with well-developed parapophyses; [2] all ribs articulate with deep pits on the lateral side of all abdominal centra.

20. Epineurals and epipleurals in the caudal region: [0] absent; [1] present.

21. Epicentrals: [0] absent; [1] present.

22. Shape of cleithrum: [0] L-like (having a single angle in the bone); [1] S-like (having two angles).

23. Dorsal process of posttemporal: [0] slender and sharp; [1] sub-rectangular; [2] broad, wider at distal tip than at midpoint of bone.

24. Number of anal fin rays: [0] eight to eleven; [1] fourteen or fifteen; [2] seventeen or eighteen; [3] twenty; [4] twenty-two to thirty-two; [5] thirty-six to forty-one.

25. Number of dorsal fin rays: [0] eight to thirteen; [1] fourteen to nineteen; [2] twenty-one to twentyfive.

26. Number of hypurals: [0] seven; [1] six; [2] five.

27. Hypural 2: [0] autogenous; [1] fused to first ural centrum (diural terminology).

28. Length of hypural 1: [0] long, reaching ural centrum 1; [1] short, not reaching ural centrum 1.

29. Proximal end of hypural 1 (was originally termed "articulation of hypural 1): [0] massive and forming an upward process; [1] sharp; [2] massive but no upward process.

30. Shape of hypural 2: [0] Distal end distinctly broader than proximal end; [1] very thin and stick-like.

31. Diastema between second and third hypural: [0] third hypural not expanded posteriorly leaving a gap or notch between the second and third hypural; [1] third hypural expanded posteriorly, leaving no gap or notch between second and third hypural.

32. Shape of diastema between hypurals 2 and 3: [0] small triangular notch; [1] deep triangular cavity; [2] large concavity formed by hypural 3 having a concave ventral edge. 


\section{RH - FOREYCLUPEA FROM NORTHWEST TERRITORIES}

33. Size of first ural centrum (diural terminology): [0] roughly the same size (length and depth) as the preuralcentra; [1] much smaller than the preuralcentra.

34. Number of uroneurals: [0] three; [1] two; [2] one.

35. First uroneural: [0] extends anteriorly to reach second preural centrum; [1] does not reach second preural centrum.

36. Fusion of first uroneural and first ural centrum: [0] absent; [1] present.

37. First uroneural bearing a dorsal expansion of laminar bone: [0] absent; [1] present.

38. Distal end of second uroneural: [0] reaching the distal end of the first uroneural; [1] not reaching the distal end of the first uroneural.

39. Parhypural: [0] base/arch of bone fused with preural centrum 1; [1] autogenous.

40. Fusion of hypural two and first ural centrum: [0] absent; [1] present.

41. Number of epurals: [0] three; [1] two; [2] none, or those present are weakly ossified, perhaps cartilaginous.

42. Position of epurals: [0] epurals fill the space between the neural spines of pu1 and pu2; [1] epurals are located far from the spine of pu2, leaving an open space between them.

43. Caudal scutes: [0] absent; [1] present.

44. Neural spine of first preural centrum: [0] large or lanceolate; [1] short or sub-rectangular.

45. Neural arch of first ural centrum: [0] absent; [1] present.

46. Predorsal scutes: [0] absent; [1] present.

47. Predorsal scute series: [0] incomplete (absent in anterior part); [1] complete.

48. Subrectangular scutes (i.e., scutes significantly broader than long) in anterior part of predorsal series: [0] absent; [1] present.

49. Subrectangular scutes in posterior part of predorsal series: [0] absent; [1] present.

50. Series of spines on the posterior margin of the lateral wings of the predorsal scutes: [0] absent; [1] present.

51. Prominent median strong spine on posteriormost predorsal scutes: [0] absent; [1] present. 


\section{RH - FOREYCLUPEA FROM NORTHWEST TERRITORIES}

52. Size of scutes of predorsal series: [0] all scutes of same size; [1] irregular in size, size of scutes increasing posteriorly.

53. Surface of predorsal scutes: [0] smooth; [1] ornamented with radiating grooves.

54. Number of predorsal scutes: [0] six to fourteen; [1] sixteen to nineteen; [2] twenty to forty-one.

55. Abdominal scute series: [0] absent; [1] present.

56. Complete abdominal scute series between isthmus and anus (i.e., postpelvic scutes are present): [0] absent; [1] present.

57. Postpelvic abdominal scutes bearing very prominent and strong ventral spine: [0] absent; [1] present.

58. Size of lateral wings of abdominal scutes: [0] small; [1] large, extended upward and covering the abdominal cavity laterally for at least one quarter of the distance from ventral body edge to vertebral column.

59. Shape of lateral wing of abdominal series scutes: [0] spine-like, with large spaces between wings of scutes; [1] wide or spatula-like, with wings of adjacent scutes touching for most of their length.

60. Postdorsal scute series: [0] absent; [1] present.

61. Number of abdominal scutes (in some taxa they will not be equivalent to vertebral counts): [0] fewer than 20; [1] 22-30; [2] more than 32.

62 Number of predorsal bones: [0] 10 or more; [1] 7-9; [2] 6 or fewer. 


\section{RH - FOREYCLUPEA FROM NORTHWEST TERRITORIES}

APPENDIX 2. Data matrix used in the phylogenetic analysis of the Early Cretaceous clupeomorphs

(based on the data matrices of Murray and Wilson (2013) and Alvarado-Ortega et al. (2008)).

\begin{tabular}{|c|c|c|c|c|c|c|c|}
\hline & 0000000001 & 1111111112 & 2222222223 & 3333333334 & 4444444445 & 55555555566 & 66 \\
\hline & 1234567890 & 1234567890 & 1234567890 & 1234567890 & 1234567890 & 1234567890 & 12 \\
\hline Chanos chanos & $0100-? 20 ? 0$ & $01 ? 0001001$ & 1100110111 & $00-1-10110$ & 100100---- & $----0----0$ & -0 \\
\hline Chirocentrus dorab & 010??10100 & 0110002101 & 1014111111 & 0110110011 & 100100---- & $----10-100$ & $? ?$ \\
\hline Denticeps clupeoides & $0100 ? 02110$ & 0010110021 & 1014021020 & 0102101101 & 100110---- & ----110000 & 0 ? \\
\hline Odaxothrissa vittata & $0100 ? 10110$ & $01100111 ? 1$ & 1012111111 & 0110110011 & 000100---- & ----110100 & 00 \\
\hline Ornategulum sardinoides & 0001100001 & $0111 ? 12001$ & $? 010101121$ & $? ? 00001001$ & 000100---- & ----0----0 & $? 0$ \\
\hline Ellimma branneri & $00011 ? ? ? 01$ & $0 ? ? 1 ? 10 ? 1 ?$ & $? 1011110 ? 1$ & 0100000001 & $0011 ? 11110$ & 1110111110 & 11 \\
\hline Ellimmichthys goodi & 1??031??00 & ??????0110 & 1110111000 & $0 ? 00001000$ & 0010111110 & 1112111110 & $? ?$ \\
\hline Ellimmichthys longicostatus & $1 ? ? 11 ? ? 00 ?$ & 0???100110 & 1110111000 & $0 ? 00001000$ & 0110111110 & 1112111110 & $? ?$ \\
\hline Ellimmichthys maceioensis & $1 ? 110 ? ? ? 0 ?$ & ?????0??? & $? 1 ? 11 ? 102 ?$ & $1-01000101$ & 0101111010 & $11101111 ? 0$ & 21 \\
\hline Ezkutuberezi carmenae & $100 ? 0 ? ? ? 0 ?$ & ????00111 & $? 1 ? 42 ? 1021$ & $? ? 0 ? 0000 ? 1$ & $100101 ? ? 00$ & $111 ? 111100$ & 20 \\
\hline Foreyclupea loonensis & $00010 ? ? ? 0 ?$ & 01?????011 & ?00?1????? & ????????? & ?????0---- & ----111000 & 0 ? \\
\hline Paraclupea chetungensis & $10011 ? ? ? 01$ & 0??1010??? & $? 1 ? 1111011$ & 0100000101 & 0111010-10 & 1111111110 & 21 \\
\hline Pseudoellimma gallae & $11 ? 101010 ?$ & 0????00001 & $? 0 ? 1121001$ & $00 ? 0000001$ & $? ? ? 0 ? 1 ? ? 10$ & $1 ? 0 ? 111000$ & 10 \\
\hline Ranulfoichthys dorsonudum & $00010 ? ? 001$ & 0111101011 & $? 000111001$ & $1-00000001$ & 0011?0---- & ----111000 & 10 \\
\hline Santanaclupea silvasantosi & $010101010 ?$ & 0??1??000? & $? 0 ? 0121001$ & $00 ? 1000001$ & ???100---- & ----111010 & $1 ?$ \\
\hline $\begin{array}{l}\text { Scutatuspinosus } \\
\text { itapagipensis }\end{array}$ & $00010 ? ? ? 01$ & $01 ? 1100111$ & 0100010021 & $1 ? 01100000$ & 0111011001 & $11101110-0$ & 10 \\
\hline Triplomystus applegatei & 10011????1 & 00????011? & $? 1121 ? 1011$ & 0011100101 & 0010111010 & 1110111111 & 22 \\
\hline
\end{tabular}

